\title{
Reading as Transformational Journey From Homer to Borges
}

\author{
Robin McAllister \\ Sacred Heart University, Fairfield, USA
}

\begin{abstract}
The transformational journey archetype begins long before literature in rites of initiation when a child undergoes a journey full of tests and temptations, perilous encounters in an underworld, and visions that transform the child into a member of a tribe. Before this archetype is translated by the written word into literature, the telling of the story is not just the account of something that happened long ago in the past, but an actual reenactment of the events for the audience. The journey archetype appears in the earliest example of literature, Homer's Odyssey, where Homer makes the readers both an observer and participant in the transformation. The journey does not always, as in rites of initiation, involve a child and occur only once in life. Instead, the journey may begin in death and trauma and involve a person who must resume that journey over again as an adult. Such is the fate of Aeneas in Virgil's Aeneid whose transformative journey begins with the burning towers of Troy. In these two early epics the heroes suffer the loss of an older world and must resume their pursuit of new identities in a new world after descending to a land of death or underworld to consult ancestor figures who prepare them for the transition to a new life, identity, and destiny. The reader of these works participates in the journeys the heroes undertake and learns to renew contact with the sources of life and consciousness in myth, magic, and vision. Dante's journey through the Inferno to his vision of God in Paradiso is a culmination of this transformative experience and vision, whose intent is to transform us as well through imaginative and intellectual participation in the journey. In Jorge Luis Borges's parody of Dante in his story, “El Aleph”, Borges goes beyond Dante in making the reader, not only a participant in the journey and vision, but a "writer” whom Borges evokes to transform the impossible vision of the Aleph into an illusion of reality. Unlike Dante's positive transformational vision of the universe as a harmonious cosmos embraced within the vision of God as if it were a book uniting its multiple pages in one binding, the vision of the Aleph confronts the protagonist and readers with a universe that is random and chaotic, a vision that is disillusioning rather than transformational.
\end{abstract}

Keywords: transformational journey, reading, rite of initiation, Homer, Virgil, Dante, Borges

\section{Introduction}

The story of transformational journeys begins long before literature, (that is, long before stories are translated into a written language used by a civilized urban people), in oral narrative, myth, rites of initiation, and shamanic spirit journeys. An amazing transition takes place when stories based on rites of initiation and shamanic journeys are translated into literature. The hero or the person who undertakes the journey changes, no longer a child whose journey full of tests, trials, perilous encounters, and visions changes him once and for all into a man or fully accepted member of a tribe, but an already mature man, an older man who has already lived a full existence in one kind of world, who suddenly has to make a difficult transition into a new, unfamiliar

Robin McAllister, associate professor, Department of English, Sacred Heart University. 
world. The journey of transformation does not necessarily end in a transformative vision, but, instead, must be resumed again and again.

The story of transformational journeys begins in a dream. These are some of the images: Burning towers, weeping, angry women, covered in blood from their lovers swords, smoke from a funeral pyre visible far out at sea. A boat with oars and a single square sail suspended on the surface of the blue sea, dense, black clouds on the horizon, flashes of lightening; the dark belly of a wooden horse; grey limestone cliffs along wooded river valleys; caves with small hidden mouths that open up into visions of horses and bison, rivers of fire and blood, dark forests concealing a gleam of gold in their green canopies; a Redtail Hawk crossing a high blue sky above a distant mountain range; an horizon of grass that never gets closer and never farther away no matter how long you walk away from a sun that is forever setting; pronghorn antelope standing silently in a circle of yellow hills visible only to the spiritual eye; Blood, a pit of blood with almost transparent ghosts flitting above and around a man with a sword waiting for a blind prophet; but above all burning towers, caves, and winding paths.

\section{Rites of Initiation}

All stories of journeys seek to achieve the transformative closure of rites of initiation. Mircea Eliade writes:

The term initiation in the most general sense denotes a body of rites and oral teachings whose purpose is to produce a decisive alteration in the religious and social status of a person to be initiated. In philosophical terms, initiation is equivalent to a basic change in existential condition; the novice emerges from his ordeal endowed with a totally different being from that which he possessed before his initiation; he has become another. Among the various categories of initiation, the puberty initiation is particularly important for an understanding of premodern man. These "transition rites" are obligatory for all the youth of the tribe. To gain the right to be admitted among adults, the adolescent has to pass through a series of initiatory ordeals: it is by virtue of these rites, and of the revelations that they entail, that he will be recognized as a responsible member of the society. Initiation introduces the candidate into the human community and into the world of spiritual and cultural values. He learns not only the behavior patterns, the techniques, and the institutions of adults but also the sacred myths and traditions of the tribe, the names of the gods and the history of their works; above all, he learns the mystical relations between the tribe and the Supernatural Beings as those relations were established at the beginning of Time. (Eliade, 1965, p. x)

Rites of initiation often take the form of journeys. Stories about these journeys make up not only our most ancient legends, but our most contemporary poetry and fiction. The story contains the same motifs, a protagonist, someone who is searching and struggling for something, which goes on a journey into an unfamiliar world, full of adventures that test and tempt him physically and spiritually. There is a descent into an underworld, often a cave, where he leaves behind the world of the living, or at least his prior familiar world, and encounters the dead, the ancestors, and the sacred realm of the gods. There is a crucial encounter with the ancestors which results in a vision of the spiritual reality underlying appearances in the world of the living to which the protagonist will return, transformed and perhaps rewarded with marriage and sovereignty. The journey is a symbolic death and rebirth, the death of a prior self and the emergence of a new identity. At least this is the form the story takes in the journeys Odysseus, Aeneas, Dante, and Borges take.

It is not just the journey that is transformative. The telling of story of the journey is transformative also. Before this story is translated by the written words into literature, the telling of the story is not just an invention or the account of something that happened long ago in the past but an actual reenactment of the events with the actual presence of the ancestors evoked for an audience who are not just listeners but participants in the events themselves. Eliade explains this commonplace miracle from an oral, traditional society: 
Whereas "false stories" can be told anywhere and at any time, myths must not be recited except during a period of sacred time (usually in autumn or winter, and only at night). This custom has survived even among peoples who have passed beyond the archaic stage of culture. Among the Turco-Mongols and the Tibetans the epic songs of the Gesar cycle can be recited only at night and in winter. The recitation is assimilated to a powerful charm. It helps to obtain all sorts of advantages, particularly success in hunting and war...Before the recitation begins, a space is prepared by being powdered with roasted barley flour. The audience sit around it. The bard recites the epic for several days. They say that in former times the hoofprints of Gesar's horse appeared in the prepared space. Hence the recitation brought the real presence of the hero. (Eliade, 1963, p.10)

Rarely, if ever, does the reader of a work of literature feel this power of immediacy in oral narrative that seems to abolish momentarily the boundaries of time, making an event from the past a present reality, abolishing the boundaries between story, poet, and audience, making the listener of the story a participant in events re-enacted once more in a kind of dreamtime set apart or outside the successive moments of ordinary time, but this preliterate response to narrative and its transformative power underlies a more sophisticated, critical response to the literary work.

\section{Homer}

Literature, the transformation of myth and legend into a written form, provides a different kind of transformation, one that can be examined in a curious, highly stylized passage from one of the first epics ever translated into written form, Homer's Odyssey. The epic simile in this passage, the oldest, most traditional of literary devices, conceals the power of the literary work to make its readers both participants and observers of the experience literature conveys. This detachment or alienation that makes analysis as well as participation possible comes at the price of the total imaginative involvement of oral narrative. The subject of this passage is Odysseus' own personal response to an oral bard, Demodocles, reciting an oral epic, the story of Odysseus' own adventures in the Trojan War, specifically the story of Odysseus' strategem of building a wooden horse and filling it with armed warriors to bring down at last the city of Troy:

And Odysseus let the bright molten tears run down his cheeks, weeping the way a wife mourns for her lord on the lost field where he has gone down fighting the day of wrath that came upon his children. At sight of the man panting and dying there, she slips down to enfold him, crying out; then feels the spears, prodding her back and shoulders, and goes bound into slavery and grief. Piteous weeping wears away her cheeks: but no more piteous than Odysseus' tears, cloaked as they were, now, from the company. Only Alkinoos, at his elbow knew. (Homer, 1963, pp. 140-41)

Those tears will force Odysseus to reveal his true identity at last and tell the story of his wanderings after the fall of Troy. He himself will be the narrator of his own story, the story of a transformative journey, a rite of initiation strangely altered by its passage from oral legend into literary epic. Although the incident portrays a moment of oral narrative, similar to that described above in which past events are momentarily for Odysseus as real and present once again as the footprints of Gesar's horse, this narrative response is presented to us within the context of the written medium of literature, and Odysseus represents a response to narrative performance that marks the transition from oral myth to literature.

Why does Odysseus weep? He not only relives the events of a past life, but realizes for the first time that he is as altered and alienated from that prior identity as a woman who in one moment of battle loses her husband, her former glory, and happiness, and is carried into slavery. Odysseus is both the wife, the woman who weeps, and the dead warrior, the old Odysseus left behind on the field of Troy. As he listens to the story of his former life, he relives the events and participates in them once again. Odysseus had spent ten years fighting 
before the walls of Troy. He was present when Achilles struck down Hector and dragged the body behind a chariot in the dirt three times around the walls of Troy before the eyes of Hector's wife, mother, and infant son. He watched Achilles die with Paris' lucky arrow shot to his ankle tendon. He hardly thinks about the night he crept out of the belly of a wooden horse and began setting fire to Troy. He was present the day after the fall of Troy when Hector's infant son is torn out of the arms of his mother Andromache and thrown off the wall of Troy to his death. Andromache is the woman who now returns as a metaphor or simile for his own present self, weeping not just for a dead warrior husband, but for that dead, former self of a heroic age that is now legend and story. When story is translated into the new technology of writing or literature, a certain distance takes place that removes the reader and poet from the immediacy of myth and total participation. Language itself is a technology for translating, storing, and transmitting experience. Within the context of a written language the old world of oral myth is seen from a new perspective, both detached and passionately involving, just as Odysseus suddenly both relives his past and contemplates it with sorrow and detachment as if he were Andromache or another woman weeping over the body of her slain husband.

When our story of the transformative journey as embodied in myth and rites of initiation enters the realm of literature, the rite of initiation is radically displaced and transformed. The story Odysseus tells of his own adventures, the most famous episodes of the Odyssey, resembles a rite of initiation, but a rite of initiation, not for a child assuming his adult identity and role in the tribe for the first time, but for a man who has already lived through one existence, an heroic existence that has been left behind on the battlefield of Troy, and now must seek a new role and identity in a post-war world, a world in which he is no longer as king but a shipwrecked refugee and beggar.

Odysseus's journey takes him from the burning city of Troy, brought to final destruction not by the heroism of battle and individual combat, the story of the Iliad, but by Odysseus' deception of the wooden horse secretly filled with armed warriors, to a world of magic and violence that delays his return to his former home. Odysseus's journey is an attempt to return home after 20 years of war, an attempt to return home to a world that has changed since he first left 20 years earlier to fight a war in Troy. He cannot return to the same world he left. There are indications throughout the Odyssey that Odysseus is dead, that his attempt to return to the home in Ithica he left and the wife who waits for him faithfully but hopelessly, is similar to returning from the dead, a ghost, and a memory, for those now living where once he reigned. When we see him first, he is living a suspended existence, godlike, on Kalypso's island, with the goddess's promise to render him immortal if he will give up his attempt to return home and remain forever with her in a paradise suspended in time.

Odysseus's journey takes him through a series of adventures that test and tempt his will to return home. As in a rite of initiation there is a cave, a journey to the land of the dead, a crucial encounter with the ancestor, Teiresias, the blind prophet, reveals to Odysseus the future events that await him upon his return to the land of the living and the steps he must take or avoid in order to make his way home again. Odysseus comes closest to physical extinction in the cave of the Cyclops. He is tested physically and mentally. To escape with his life, he has to conceal his real name and invent a new name that fits all identities or none. When Polyphemus asks him his name, Odysseus answers, "Nobody". He has no identity, his old identity is hidden or annihilated in the cave of the Cyclops, and he can assume any or every disguise he requires to escape death. Emerging from the mouth of the cave, clinging to the belly of sheep, Odysseus is reborn into the new world of the goddess Circe, a goddess of love and death, who hold the keys to a journey to the land of the dead. She can transform men into panthers, wolves, and swine, and bring them back transformed again into younger and stronger versions of 
themselves. Only through her, by his participation in a sacred marriage with her, can Odysseus journey to the land of the dead, speak with the oracular ancestor ghost, Tireseias, and receive a vision that instructs him how to return to his true home. He stands over a pit of blood on the beach of a sunless, shadowy world where ghosts flicker and flitter unsubstantially around his head like bats coming out of a cavern at twilight and holds a sword out keeping back both the ghost of Alpenor, whose life is the symbolic sacrifice that allows Odysseus to go to the land of death and return again without leaving his own life behind there, and even driving away the ghost of his own mother who pleads for her son's pity, until the ghost of the prophet most famous for solving the riddle of the hero Oedipus' true identity as both son and husband, father, and brother, can drink the sacrificial blood and speak. Odysseus will return from the land of the dead with a prophesy of the future that helps him survive the sirens, the clashing rocks, the whirlpools, and famine on the island of the Sun, and shipwreck. But he returns to an Ithica where he is no longer recognized, except by his old dog Argos, and where he is a beggar, a servant to his former servant, the swineherd Eumaeus. The rest of Odysseus's story: The battle with the suitors; stringing his old bow and shooting an arrow through rings set up as a target; his reunion with his wife Penelope. Retiring with her to his own marriage bed to reconfirm their union. His journey is over, but not over. He has been transformed from warrior to beggar to king once again, but there is no final closure. We never see him complete the final destination prophesied by Teiresias, a final voyage and journey at the end of his life in search of a land, another land of the dead, where no one has ever seen the restless waves of the sea or heard of the oar of a ship.

\section{Virgil}

We next encounter the story of a transformative journey in the lines of Virgil's literary epic of the Roman Empire, the Aeneid. Aeneas, as we remember, is a Trojan warrior who has been defeated by Odysseus and the Greeks. He will tell Dido, the Queen of Carthage, his own version of the last night in Troy, when the city fell to the Greeks, and Aeneas barely escapes the burning towers and falling walls of Troy, carrying his father on his back and leading his young son by the hand. He will leave his wife behind in the burning city, lost and separated from him in the confusion of escape. Aeneas has to start life all over again after surviving a catastrophe, but he seems doomed to repeat the events he has escaped from over and over again. For him the rite of initiation is transformed from a ritual a boy goes through only once in life to a journey and ordeal repeated every time. An already mature adult must make a difficult passage from one existence in a former world to a life in a changed world. Once again a man flees the flames of his conquered city. For a while after he is shipwrecked, he lives with another refugee, Dido, the queen of Carthage, who consummates a sacred marriage with him in a cave during a rainy tempest, until the god Mercury interrupts their bliss and orders Aeneas to recall the destiny promised to him as the founder of the future Roman empire, secretly prepare his ships to flee, and leave Dido, regardless of their love for each other. As he sails away he can look back over the sea to another column of smoke soaring above the ruins of a city, this time the smoke from Dido's funeral pyre as it consumes the remains of her suicide and dooms Carthage to future war and destruction at the hands of Aeneas' Roman descendants. Once again Aeneas abandons a woman and flees the flames rising from a doomed city.

In order to leave the old Aeneas of Troy, Dido, and the Trojan War behind and assume his new identity as a Roman, Aeneas must also journey to the Underworld, speak with the ancestors, the ghost of his father Anchises in this case, and receive a vision of the future history of Rome. But his descent and return is not 
necessarily a transformative experience. He is not just reborn into a new world, but a new world that repeats the pattern of the past. As the Sibyl tells him in her prophetic trance before she will guide him down through the winding cavern of the Underworld and back again:

0 you that at last have done with the dangers of the deep (Yet graver ones await you on land), the Trojans shall come to power in Lavinium-be troubled no more about this-But shall not be glad they did. Wars, dreadful wars I see, and Tiber flowing with torrents of human blood. You will not escape a Simois, a Xanthus there, a Greek encampment; Latium has a new Achilles in store for you, he too a goddess' son...Once more it's an alien bride, a foreign marriage that's destined to cause such terrible harm to the Trojans. (Day Lewis, 1952, p. 132)

We seek in vain for a final transforming experience to conclude Aeneas' story. Instead of rebirth when he returns from his journey to the Underworld, Aeneas is plunged back into a world of war, and his story breaks off abruptly in a sudden act of homicidal fury that seems to refute and cancel out his own painfully acquired virtues of self-restraint, rational control of the passions, and the rule of law. His story must await completion by a future reader and author, Dante, who will continue the story of the transformative journey and bring it to its most divine conclusion.

\section{Dante}

Dante too is a refugee of civil war and an exile from his beloved city and home of Florence. He too, like Aeneas, must begin a new life all over again, after surviving a catastrophe that ends his old world. In April of 1300, Dante finds himself in midlife lost in dark woods. He sees the sun illuminating the top of a mountain, but when he tries to climb the slope, he is driven back by a leopard, a lion, and a wolf. Before he can climb out of the dark woods and experience the spiritual rebirth he seeks, he needs a guide who can take him to the world beyond and bring him safely back to the world of the living. His journey will resemble a rite of initiation, once again for a person who has survived the death of a former world and seeks a transformed identity in a new world. His Christian rite of initiation is telescoped into the descent into the underworld with its symbolic death and his return up the mountain of Purgatory to ascend the spheres of the heavens, where he will meet the soul of his own ancestor and receive a transformative vision from God himself.

Aeneas' Underworld is a deep volcanic cave, Avernus, still emitting sulphur fumes that kill any bird that tries to fly across its mouth. The Sibyl compares the winding cave to the legendary labyrinth of Crete built by Daedalus to hide the Minotaur: “...The way to Avernus is easy; night and day lie open the gates of death's dark kingdom: But to retrace your steps, to find the way back to daylight-that is the task, the hard thing” (Day Lewis, 1952, pp. 133-4). Dante's journey seems to have begun with his reading of Virgil's Aeneid, since he chooses Virgil rather than the Sibyl to lead him into the Inferno and back out again, up the terraces of the mountain of Purgatory, and into the Garden of Paradise, before Dante will ascend through the spheres of heaven to the presence of God. Aeneas' journey into Avernus preserves details that point to the origin of this journey in rites of initiation and shamanic journey, as James Frazier acknowledges by entitling his own epic study of mythology, The Golden Bough, in reference to the talisman, perhaps mistletoe, that sanctions Aeneas' descent into the underworld. Aeneas' descent is preceded by the Sibyl's trance or possession by the god Apollo. As Eliade tells us, the shamanic ecstasy is a spiritual journey, not unlike the puberty rite of initiation, in which the shaman leaves the world of the living, flies to the world of the spirits and ancestors, and returns to the world of the living with healing and knowledge. Aeneas will retrace the steps of a rite of initiation with all its accompanying symbols of death and rebirth. The golden bough symbolizes immortality, or life even in the 
death of winter. Aeneas discovers it with the help of his mother Venus' doves while he and his shipmates are cutting trees for the funeral pyre of one of their companions. The apparently accidental death of Misenus functions as a sacrificial death that provides the necessary life that enables Aeneas to return from the land of the dead with his own life.

Dante would not have interpreted these events in a mythological way, but he might well have been astounded to find that Virgil's Underworld contains not just Tartarus, a place of punishment like Hell, but a Paradise, the Elysian fields, and a kind of Purgatory where the souls of the dead are prepared for a return to life on earth. Aeneas's ancestor spirit, the ghost of his father, presides over this vision of future souls, among which Aeneas will see the souls of his descendants, the future emperors of Rome:

Now did Aeneas descry, deep in a valley retiring, a wood, a secluded copse whose branches soughed in the wind, and Lethe river drifting past the tranquil places. Hereabouts were flitting a multitude without number, just as, amid the meadows on a fine summer day, the bees alight on flowers of every hue, and brim the shining lilies, and all the lea is humming with them. Then his father, Anchises, said:- They are souls who are destined for reincarnation; and now at Lethe's stream they are drinking the waters that quench man's troubles, the deep draught of oblivion. But, father, must it be deemed that some souls ascend from here to our earthly scene? Re-enter our dull corporeal existence? Why ever should so perverse a craving for earth possess them? First, you must know [answered Anchises] that the heavens, the earth, the watery plains of the sea, the moon's bright globe, the sun and stars are all sustained by a spirit within; for immanent Mind, flowing through all its parts and leavening its mass, makes the universe work. This union produced mankind, the beasts, the birds of the air, and the strange creatures that live under the sea's smooth face. The life-force of those seeds is fire, their source celestial, but they are deadened and dimmed by the...bodies they live in the flesh that is laden with death, the anatomy of clay: whence these souls of ours feel fear, desire, grief, joy, but encased in their blind, dark prison discern not the heaven-light above. Yet, not even when the last flicker of life has left us, does evil, or the ills that flesh is heir to, quite relinquish our souls; it must be that many a taint grows deeply, mysteriously grained in their being from long contact with the body. Therefore the dead are disciplined in purgatory, and pay the penalty of old evil. All these souls, when they have finished their thousand-year cycle, God sends for, and they come in crowds to the river of Lethe, so that, you see, with memory washed out, they may revisit the earth above and begin to wish to be born again. (Day Lewis, 1952, pp. 151-2)

It is apparent here in Virgil's words how Dante could have read these lines as a foreshadowing or anticipation of the Christian concept of the afterlife, a mistaken pagan view, reincarnation in particular, but nevertheless an anticipation of what Dante finds as he follows Virgil through the Inferno. Dante's journey is the now familiar rite of initiation we have seen with Odysseus and then Aeneas, a rite of passage for a displaced, refugee, or survivor of a catastrophe, the death of an old life and the search for meaning and identity in a changed world. In no other literary journey do we end with a vision of the power Dante gives us, however, as, in the last lines of Paradiso, he tries to narrate his actual experience of spiritual transformation as he sees God in the form of a beam of light that exceed human understanding:

From that moment my vision was greater than my speech, which fails at such a sight, and memory too fails at such excess. Like him that sees in a dream and after the dream the passion wrought by it remains and the rest returns not to his mind, such am I; for my vision almost wholly fades, and still there drops within my heart the sweetness that was born of it. Thus the snow loses its imprint in the sun; thus in the wind on the light leaves the Sibyl's oracle was lost. 0 Light Supreme that art so far exalted above mortal conceiving, grant to my mind again a little of what thou appearedst and give my tongue such power that it may leave but a gleam of thy glory to the people yet to come; for by returning to my memory and by sounding a little in these lines the better conceived will by thy victory. I think, from the keenness I endured of the living ray, that I should have been dazzled if my eyes had been turned from it; and I remember that for this cause I was the bolder to sustain it until I reached with my gaze the Infinite Goodness. 0 abounding grace, by which I dared to fix my look on the Eternal Light so long that I spent my sight upon it! In its depth I saw that it contained, bound by love in one volume, that which is scattered in leaves through the universe, substance and accidents and their relations as it were fused together in 
such a way that what I tell of is a simple light. I think I saw the universal form of this complex, because in telling of it I feel my joy expand. A single moment makes for me deeper oblivion than five and twenty centuries upon the enterprise that made Neptune wonder at the shadow of the Argo. Thus my mind, all rapt, was gazing fixed, still and intent, and ever enkindled with gazing. At that light one becomes such that it is impossible for him ever to consent that he should turn from it to another sight; for the good which is the object of the will is all gathered in it and apart from it that is defective which there is perfect. Now my speech will come more short even of what I remember than an infant's who yet bathes his tongue at the breast. Not that the living light at which I gazed had more than a single aspect-for it is ever the same as it was before-,but by my sight gaining in strength as I looked, the one sole appearance, I myself changing, was, for me, transformed. In the profound and clear ground of the lofty light appeared to me three circles of three colours and of the same extent, and the one seemed reflected by the other as rainbow by rainbow, and the third seemed fire breathed forth equally from the one and the other. a how scant is speech and how feeble to my conception! And this, to what I saw, is such that it is not enough to call it little. A Light Eternal, that alone abidest in Thyself, alone knowest Thyself, and, known to Thyself and knowing, lovest and smilest on Thyself! That circling which, thus begotten, appeared in Thee as reflected light, when my eyes dwelt on it for a time, seemed to me, within it and in its own colour, painted with our likeness, for which my sight was wholly given to it. Like the geometer who sets all his mind to the squaring of the circle and for all his thinking does not discover the principle he needs, such was I at that strange sight. I wished to see how the image was fitted to the circle and how it has its place there; but my own wings were not sufficient for that, had not my mind been smitten by a flash wherein came its wish. Here power failed the high phantasy; but now my desire and will, like a wheel that spins with even motion, were revolved by the Love that moves the sun and the other stars. (Dante, 1961, pp. 481-85)

\section{Borges}

In so far as the literary medium of poetry possesses the power of oral recitation to make the reader not just a reader or observer, but a participant in the events reenacted in the story. The reader reenacts the transformational journey he or she is reading. Jorge Luis Borges in his parody of Dante's vision of God in the story, "The Aleph", goes beyond making the reader a participant to making him a "writer" who can resolve the "inexpressibility" of the vision of the universe as a microcosmic Aleph Borges cannot. Borges writes:

In that gigantic instant I saw millions of acts both delightful and awful; not one of them amazed me more than the fact that all of them occupied the same point in space, without overlapping or transparency. What my eyes beheld was simultaneous, but what I shall now write down will be successive, because language is successive. Nonetheless, I'll try to recollect what I can. (Rodriguez \& Reid, 1981, p. 161)

Dante had interrupted his narrative to invoke the presence of God to sustain his vision; Borges interrupts his narrative to invoke the presence of a reader. By denying that he Borges can find words to express the vision and negatively spelling out the conditions required to represent the totality and simultaneity of the vision, he provides the reader with an incentive to use his imagination to convert the partiality of the enumeration into totality, its successiveness into simultaneity. If the reader evokes a vision, or illusion of vision, from the paradoxical, apparently random images of the enumeration, the journey is transformed from the fictional protagonist and writer to the reader who "dreams" the fictional vision into existence as an apparently autonomous reality, to paraphrase Borges's words from his essay “Avatars of the Tortoise” (Rodriguez \& Reid, 1981, p. 109). Unlike Dante's transformational vision of the universe as a harmonious cosmos embraced within the vision of God as if it were a book binding its multiple pages in one volume, Borges's vision is apparently random and chaotic. The Aleph's appropriate image is a book whose letters mix and lose themselves when there is no longer the presence of a reader to transform their sequence into simultaneity, their partiality into totality: 
I saw a summer house in Adrogue and a copy of the first English translation of Pliny—Philemon Holland's—and all at the same time saw each letter on each page (as a boy, I used to marvel that the letters in a closed book did not get scrambled and lost overnight). (Rodriguez \& Reid, 1981, p. 161)

\section{Conclusion}

The story of the transformational journey has taken us a long way from the shaman's dream flight to the world of the spirits and back, from Eliade's words about rites of initiation in which the initiate learns "the sacred myths and traditions of the tribe, the names of the gods and the history of their works; above all...the mystical relations between the tribe and the Supernatural Beings as those relations were established at the beginning of Time” (Eliade, 1965, p. x). Dante transforms this initiatory vision into the highest realms of philosophy, theology, and poetics without breaking continuity with the most primitive origins in journey and initiation. Our own story of transformative journeys must now come to an end, but the journey is not over. Each of us continues to recapitulate these mythic patterns as we make the difficult transition from catastrophe and loss in our own lives to learning to live with a renewed sense of identity in our changed and changing world.

\section{References}

Day Lewis, C. (Trans.). (1952).The Aeneid of Virgil. New York: Doubleday Anchor Book.

Dante, A. (1961). The divine comedy: Volume 3: Paradiso. (J. D. Sinclair, Trans.). New York: Oxford University Press.

Eliade, M. (1963). Myth and reality. (W. R. Trask, Trans.). New York: Harper Torchbooks.

Eliade, M. (1958). Rites and symbols of initiation: The mysteries of birth and rebirth. (W. R. Trask, Trans.). New York: Harper Torchbooks.

Homer. (1963). The Odyssey. (R. Fitzgerald, Trans.). Garden City, NY: Doubleday.

Rodriguez, M. E., \& Reid, A. (Eds.). (1981). Borges; a reader; a selection from the writings of Jorge Luis Borges. New York: Dutton. 